\title{
Perancangan produk aplikasi resep interaktif pembuatan kue tradisional untuk anak-anak
}

\author{
Setya Putri Erdiana, ${ }^{1 *}$ Octaviyanti Dwi Wahyurini ${ }^{1}$ \\ ${ }^{1}$ Program Studi Desain Komunikasi Visual, Institut Teknologi Sepuluh Nopember, Surabaya, Indonesia
}

\begin{abstract}
Cooking can be done by all people including by kids. Parents can start to teach and give a trust to their children when they are in the school-age. Also, it's good to introduce children how to cook in the early age because cooking have many positive impacts for children. A kid who learns to cook will have healthier eating habit rather than other kids. To make them interest to learn to cook, its better if parents know what their kid wants about what kind of food they want to cook. Usually, kids feel interested to something they used to see everyday, in this case is traditional snacks. Besides, presenting traditional snack recipes as content, parents can teach them about the cultures of the origin of those snacks. Therefore, I as a designer will design an application for children with local culture as content, an interactive recipe application how to cook traditional snacks. After do many kinds of designing methods, from spreading questionnaires until observation to a sample of target audiences, hope the results can fit in the needs and solve the problems. Also this application can teach children how to cook their own food and make them proud of their own Indonesian local culture.
\end{abstract}

Key words: application, traditional snack recipes, children

\begin{abstract}
Abstrak
Kegiatan memasak dapat dilakukan oleh siapapun termasuk anak-anak. Orang tua dapat mulai mengajarkan memasak dan memberikan kepercayaan pada anak-anak usia sekolah. Bahkan anak-anak sebaiknya diperkenalkan dengan kegiatan memasak sejak dini karena kegiatan memasak memiliki banyak dampak positif bagi anak-anak. Anak yang belajar memasak akan memiliki pola makan yang lebih sehat dibandingkan anak lain seusianya. Untuk menarik minat anak dalam belajar memasak, sebaiknya Orang tua mengikuti keinginan sang anak mengenai menu yang akan dipilih. Anak-anak tertarik akan sesuatu yang sering dijumpainya dalam kesehariannya, salah satunya yakni kue-kue tradisional. Selain itu, dengan mengangkat kue tradisional sebagai kontennya, Orang tua dapat mengajarkan mengenai budaya-budaya daerah asal tempat kue tersebut. Maka dari itu, penulis akan merancang sebuah aplikasi yang ditujukan untuk anak-anak dengan mengangkat budaya lokal sebagai kontennya, yakni sebuah aplikasi resep interaktif cara membuta kue tradisional. Dengan melakukan berbagai metode perancangan, mulai dari menyebarkan kuisioner hingga observasi secara langsung terhadap target audiens, diharapkan hasil perancangan dapat sesuai dengan kebutuhan dan problematika yang ada. Aplikasi ini diharapkan dapat mengajarkan anak-anak untuk memasak makanannya sendiri dan menumbuhkan rasa bangga akan kekayaan budaya lokal Indonesia.
\end{abstract}

Kata kunci: aplikasi, resep kue tradisional, anak-anak

\section{Pendahuluan}

Kegiatan memasak dapat dilakukan oleh siapapun dari berbagai usia termasuk anak-anak. Orang tua dapat mulai mengajarkan anak-anaknya untuk memasak dan memberikan kepercayaan pada usia sekolah (Wawa, 2013). Mary Berry, ahli kuliner dari
Inggris mengatakan bahwa, anak-anak sebaiknya diperkenalkan dengan kegiatan memasak mulai dari usia 5-8 tahun, dimana anak-anak telah lancar untuk membaca dan berhitung (Dini, 2013). Dengan kemampuannya tersebut, anak-anak dapat diajak untuk membaca resep sederhana dan membantu menyiapkan bahan-bahan yang diperlukan dalam

* Corresponding author e-mail : setyaputrierdiana@gmail.com 
memasak.

Aktivitas memasak sendiri terbukti mampu menstimulasi improvisasi kaum ibu di Barat yang kemudian menjadi sebuah proses kreatif yang tanpa sadar dilakukannya (McCabe \& De Waal Malefyt, 2015). Memasak juga memiliki banyak dampak positif bagi anak-anak. Sebuah penelitian mengemukakan, anak yang belajar memasak cenderung memiliki pola makan 50 persen lebih sehat dibandingkan dengan anak yang tidak pernah belajar memasak (Sartika, 2013). Selain itu, berdasarkan riset yang melibatkan siswa di 151 sekolah di kota Alberta, Kanada, mengenai pengalaman mereka dalam memasak dan memilih makanan, didapatkan fakta bahwa anak-anak yang membantu orang tua untuk memasak, memiliki ketertarikan yang lebih besar untuk mengonsumsi buah dan sayur-sayuran (Chu et al., 2013). Melibatkan anak-anak dalam memasak dan menyiapkan makanan dapat menjadi peluang untuk mengembangkan perilaku makan yang sehat dan untuk meningkatkan konsumsi sayuran (van der Horst, Ferrage, \& Rytz, 2014).

Banyak juga manfaat yang didapatkan oleh orang tua dalam mengajarkan anak memasak. Sebuah tesis membuktikan bahwa hanya dalam waktu 4 hari mengikuti cooking camps, anak-anak peserta kegiatan tersebut meningkat kemampuan dan wawasannya secara signifikan terhadap nutrisi makanan dan tingkat keamanannya (Burdett, 2015). Dilaporkan pula setelah menjalani perkemahan tersebut, anakanak mengalami peningkatan dalam hal konsumsi buah dan sayuran.

Setiawan, M.Psi seorang psikolog anak mengungkapkan bahwa, mengajarkan anak memasak dapat meningkatkan kehangatan keluarga, meningkatkan wawasan anak, melatih konsentrasi dan daya ingat, mengembangkan sensitivitas rasa, melatih anak membuat keputusan, meningkatkan tanggung jawab, membiasakan pola makan sehat, serta memberikan rasa cinta kepada anak anak. Bahkan, menurut Rose Mini., M.Psi, seorang psikolog ternama, kegiatan memasak dapat mengasah hampir semua aspek kecerdasan anak, mulai dari kecerdasan berbahasa, kecerdasan logis metematis, kecerdasan interpersonal, kecerdasan intrapersonal, kecerdasan kinestetik, dan juga kecerdasan visual (Parenting Indonesia, 2013).

Untuk menarik minat anak dalam belajar memasak, sebaiknya Orang tua mengikuti keinginan sang anak mengenai menu yang akan dipilih. Berdasarkan hasil wawancara dengan Bapak Otje Herman Wibowo, A.md, SE, dosen pengajar pastry \& bakery Akademi Pariwisata Majapahit Surabaya mengatakan bahwa, anak-anak peserta kids cooking class di Tristar
Culinary Academy terlihat lebih antusias ketika diajarkan membuat jajanan tradisional seperti klepon dan terang bulan. Karena dalam kesehariannya, mereka sering menjumpai serta mengkonsumsi kuekue tersebut. Sehingga anak-anak merasa gembira karena mereka dapat memasaknya sendiri (Parenting Indonesia, 2013).

Dan untuk mengenalkan kegiatan memasak kepada anak-anak, diperlukan sebuah media yang tepat dan sesuai dengan gaya hidup anak-anak saat ini. Berdasarkan survey terhadap 100 anak dengan usia 812 tahun, 87 persen anak-anak memilih untuk menggunakan media digital berupa smartphone dalam mencari sebuah informasi, sedangkan sisanya yakni sebanyak 23 persen memilih untuk menggunakan media cetak seperti koran maupun buku (Tabel 1). Dengan menggunakan media digital, anak-anak dapat menemukan informasi tidak hanya berupa teks dan gambar, tetapi juga berupa audio dan audio visual yang bersifat interaktif sehingga terlihat lebih menarik bagi anak-anak. Terlebih saat ini Indonesia telah memasuki era industry 4.0, yang ditandai meningkatnya konektivitas, interaksi, dan batas antara manusia, mesin, dan sumber daya lainnya yang semakin konvergen melalui teknologi informasi dan komunikasi. Pada revolusi industri keempat ini, terjadi lompatan besar bagi sektor industri, dimana teknologi informasi dan komunikasi dimanfaatkan sepenuhnya. Maka dari itu, aspek penguasaan teknologi merupakan kunci penentu daya saing di era industry 4.0 (Kementerian Perindustrian Republik Indonesia, 2018).

Tabel 1. Diagram minat anak-anak terhadap penggunaan media dalam mencari informasi

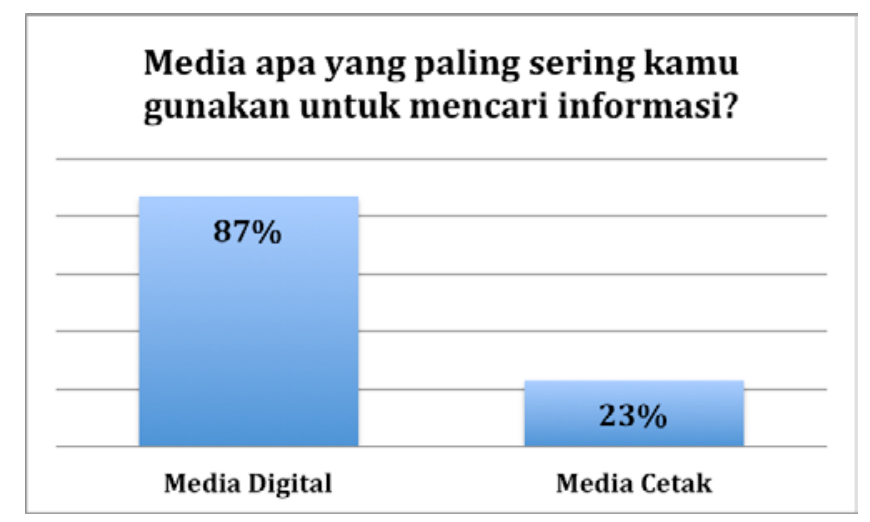

Sumber: Hasil survey terhadap 100 anak usia 8-12 tahun yang berdomisili di Surabaya dan Malang

Maka dari itu, dengan perancangan aplikasi resep interaktif cara membuat kue tradisional untuk anakanak, diharapkan anak-anak dapat mulai belajar memasak dan mengetahui proses pembuatan kue-kue 
tradisional. Selain itu, dengan mengajak anak memasak bersama-sama, orangtua sebagai pendamping dapat dengan leluasa untuk mengawasi, mengontrol, membantu proses memasak, sekaligus dapat mempererat hubungan dengan anak.

\section{Bahan dan Metode}

Dalam perancangan produk aplikasi resep interaktif pembuatan kue tradisional ini, terdapat 2 jenis data yang digunakan. Yang pertama yakni, data primer yang meliputi depth interview untuk mengumpulkan informasi secara terperinci mengenai permasalahan yang akan diangkat yang berasal dari para ahli di bidangnya. Pada perancangan ini, penulis melakukan depth interview terhadap dua narasumber yang masing-masing merupakan ahli di bidang kuliner serta ahli di bidang pembuatan aplikasi android, kuisioner untuk memahami bagaimana karakteristik audiens dan apa saja yang diinginkan oleh target audiens secara menyeluruh yang nantinya dapat dituangkan dalam output perancangan aplikasi resep interaktif ini serta observasi untuk mengamati bagaimana tingkah laku anak-anak, baik dalam kesehariannya maupun tingkah laku ketika mereka memasak. Sedangkan data sekunder meliputi informasi yang didapat dari literatur, media eksisting, serta data yang berasal dari internet.

Produk yang akan dihasilkan nantinya berupa sebuah aplikasi android yang interaktif dengan konten berupa resep-resep kue tradisional yang populer di Pulau Jawa. Konten resep kue tradisional didapatkan dari ahli di bidng kuliner, dengan memilih mana saja kue-kue tradisional yang kiranya dapat dipraktekkan oleh anak usia 8-12 tahun. Dengan memberikan fitur interaktif, diharapkan anak-anak sebagai pengguna aplikasi tersebut lebih mudah memahami proses memasak kue tradisional dan juga tidak membosankan sehingga anak-anak lebih tertarik untuk belajar memasak.

Karakteristik target audiens ini didapatkan berdasar hasil kesimpulan dari analisis kuisioner, AIO, dan juga observasi yang dilakukan oleh penulis pada tahapan riset yang telah dilakukan sebelumnya:

a. Menggemari permainan pada gadget

b. Gemar beraktivitas di luar rumah

c. Tertarik dengan karakter kartun

d. Menyukai karakter berbentuk manusia yang berproporsi lebih nyata

e. Senang menggunakan aplikasi yang berupa game atau interaktif

f. Memilih aplikasi berdasarkan gambarnya

g. Menyukai warna-warna yang playful
Kata kunci Interactive, Fun, dan Playful mengacu pada konsep perancangan produk aplikasi resep pembuatan kue tradisional untuk anak-anak. Bila dijabarkan secara denotatif, interactive memiliki arti bersifat saling melakukan aksi, antar-hubungan, dan saling aktif. Jika dihubungkan dengan perangkat komputer maka berkaitan dengan dialog antara komputer dan terminal atau antara komputer dan komputer. Sedangkan fun memiliki arti suatu kegiatan yang dapat membuat ketenangan dan terhibur. Dan playful memiliki arti penuh dengan kegembiraan dan semangat yang tinggi .

Untuk penjelasan arti konsep interactive, fun, dan playful, masing-masing kata mewakili kebutuhan target audiens yakni anak-anak usia 8-12 tahun. Interaktif menggambarkan bahwa yang disukai anakanak adalah aplikasi yang dapat dimainkan. Fun sendiri mewakili kecenderungan anak-anak yang memilih sebuah aplikasi berdasarkan ketertarikan akan gambar yang ditampilkan. Sedangkan, playful mewakili kombinasi warna-warna ceria yang disukai anak-anak. Jadi secara keseluruhan, aplikasi akan dibuat dengan gambar yang menarik bagi anak-anak dengan warna-warna ceria, dan dapat dimainkan.

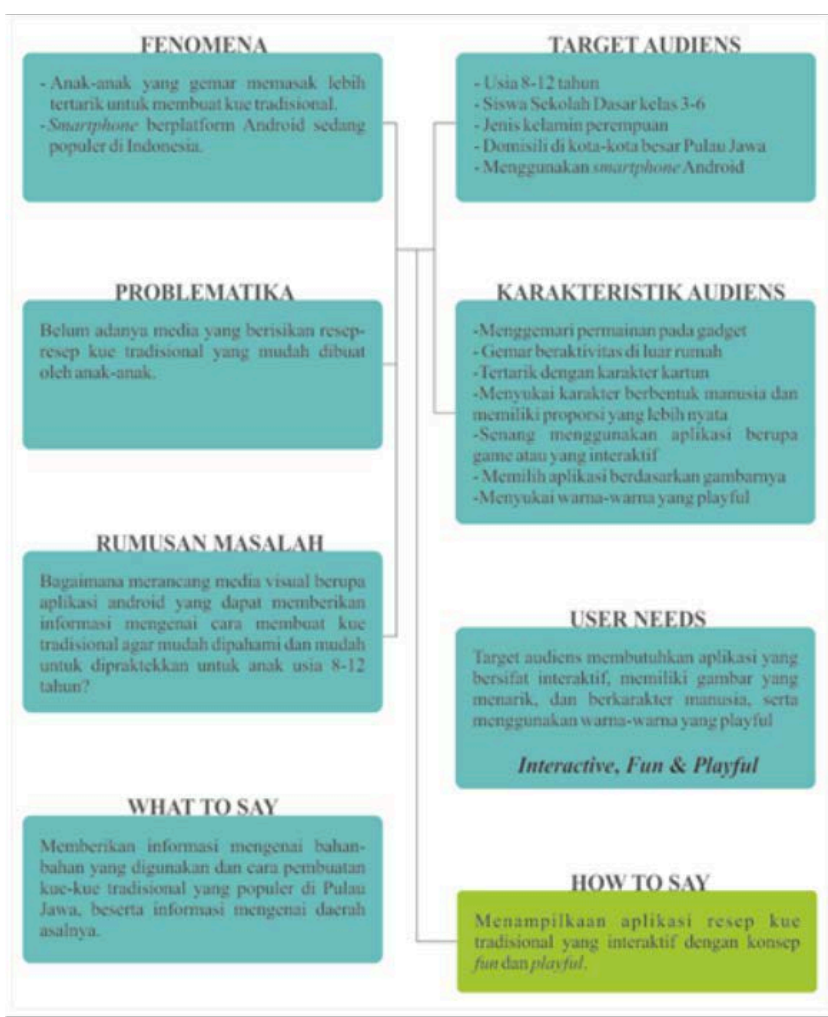

Gambar 1. Bagan konsep desain 


\section{Hasil dan Pembahasan}

Pada perancangan produk aplikasi resep ini, resepresep kue tradisional yang ditampilkan telah dipilih dan diklasifikasikan berdasarkan asal daerahnya di pulau Jawa, tingkat kesulitan dalam proses pembuatan, waktu membuat, dan kandungan nilai gizi yang ada. Terdapat 15 resep, dengan jumlah masingmasing 3 resep pada tiap provinsi yang ada di Pulau Jawa. Berikut hasil klasifikasi resep-resep kue tradisional yang berasal dari Pulau Jawa, yakni:

a. Ketan Urap, kue cincin, dan kue mangkok dari DKI Jakarta.

b. Colenak, ketimus, dan surabi dari Jawa Barat.

c. Jemblem, klepon, dan cenil dari DI Yogyakarta.

d. Wajik, getuk, dan lumpia dari Jawa Tengah.

e. Onde-onde, lupis, dan jongkong dari Jawa Timur. Seperti tampak pada Gambar 2.

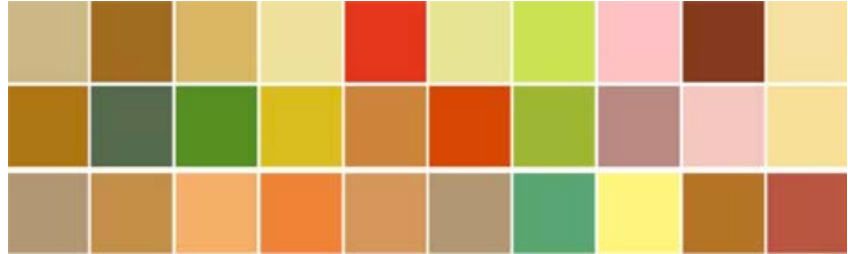

Gambar 3. Kombinasi warna tradisional (dokumentasi pribadi)

Dari hasil studi literatur, analisa objek, dan hasil kuisioner visual, maka kombinasi warna yang akan digunakan adalah kombinasi warna tradisional untuk warna pada bahan-bahan, peralatan, dan makanan serta kombinasi warna playful untuk warna environment agar memberikan kesan cerah, ceria, dan dapat menggambarkan dunia anak yang sangat aktif. Untuk kombinasi warna tradisional, didapatkan dari pallete warna kue-kue tradisional serta bahanbahannya yang ada di Pulau Jawa (Gambar 3).

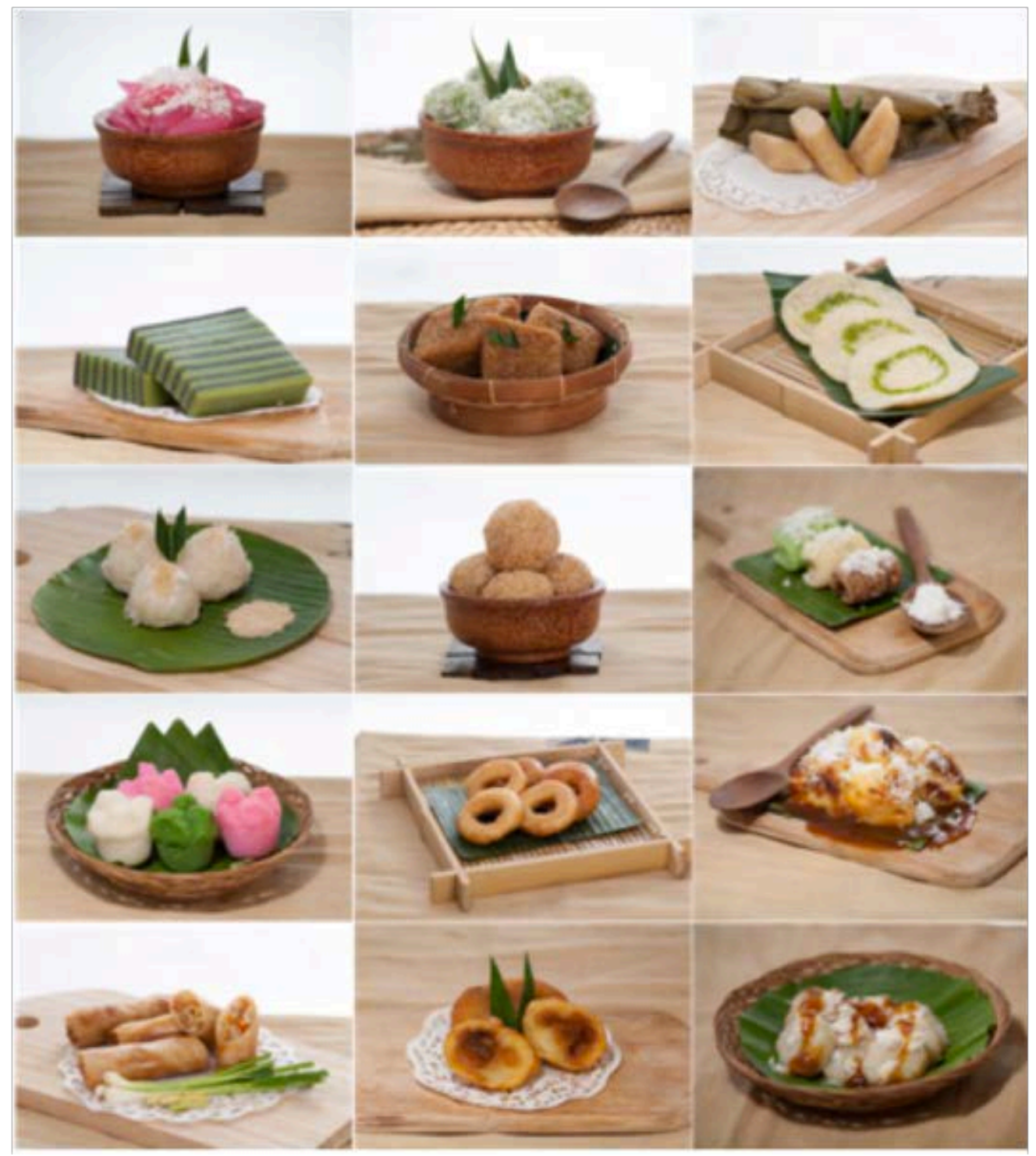

Gambar 2. Foto kue-kue tradisional yang populer di Pulau Jawa (dokumentasi pribadi) 
Kombinasi warna playful ini merupakan perpaduan dari berbagai macam warna yang colorful. Palette warna playful ini didapatkan dari warna peralatan memasak khusus untuk anak-anak. Teknik pewarnaan vector dipilih dengan pertimbangan penggunaan media berupa mobile device yang cenderung berukuran kecil, sehingga jika menggunakan teknik pewarnaan yang terlalu detail, cenderung kurang terlihat. Selain itu, dengan teknik vector ini, karakter yang ada dapat ditampilkan sesuai dengan gaya gambar favorit target audiens dan juga lebih dapat mengeksplor warna-warni yang ceria (Gambar 4).

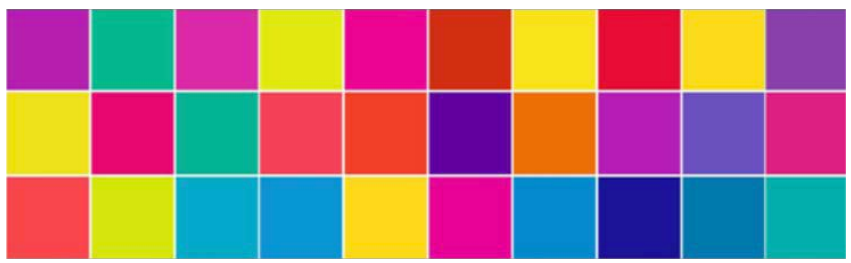

Gambar 4. Kombinasi warna playful (dokumentasi pribadi)

Dalam menggambarkan karakter utama yakni seorang anak-anak yang dapat menampilkan karakter Indonesia, maka karakter anak di adaptasi oleh anakanak usi 8-12 tahun pada umumnya memiliki postur tubuh yang pendek, agak berisi, panjang rambut sebahu dan memiliki poni depan, rambut sedikit bergelombang dan berwarna hitam, serta kulit sawo matang (Gambar 5).
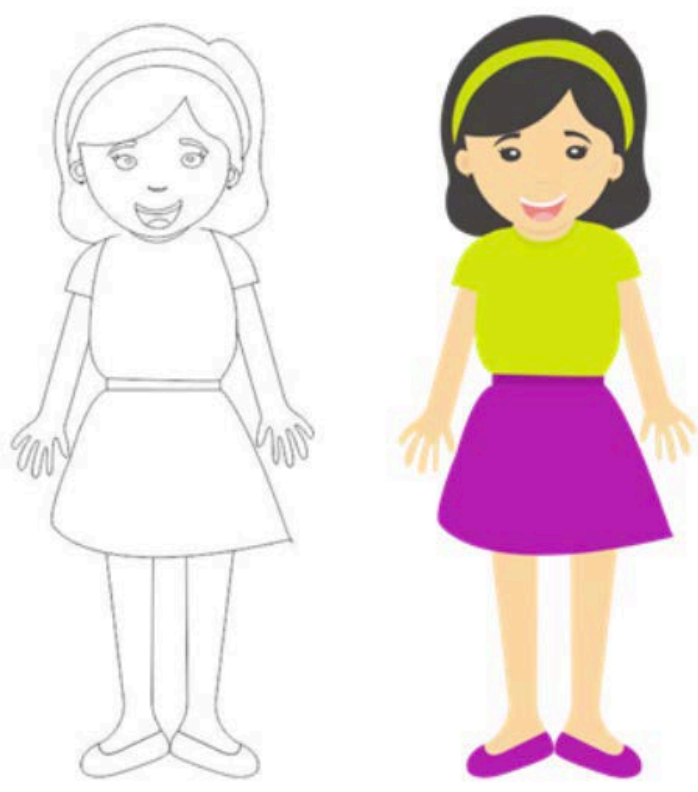

Gambar 5. Desain karakter anak usia 8-12 tahun dengan pakaian sehari-hari
Karakter anak digambarkan menggunakan pakaian sehari-hari yakni kaos dan celana pendek dengan menggunakan aksesoris yakni bando. Selain itu, ketika mengenalkan daerah asal kue tersebut, maka karakter anak akan menggunakan pakaian adat tradisional.

Untuk memberikan informasi tambahan mengenai budaya adat dari daerah asal kue tradisional, yakni berupa pakaian adat, rumah adat, tarian adat atau senjata khas. Maka budaya yang dipilih responden yang dirasa paling dapat mewakili daerah tersebut yakni Pakaian adat. Pakaian adat ini nantinya akan digunakan oleh karakter utama untuk memperkenalkan dari provinsi mana kue tersebut berasal (Gambar 6).

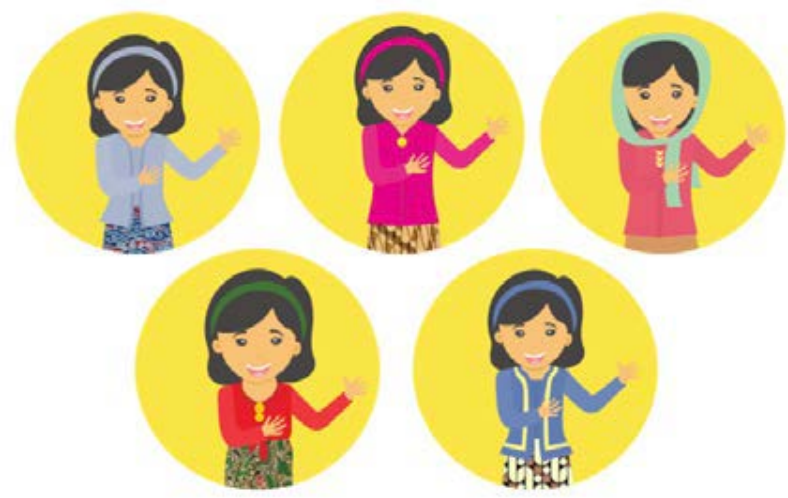

Gambar 6. Desain karakter anak menggunakan pakaian adat tradisional dari 5 Provinsi di Pulau Jawa

Selain pakaian sehari-hari dan pakaian adat, karakter anak-anak juga ditampilkan dengan menggunakan accesories yang biasa mereka gunakan saat memasak, yakni topi koki dan juga celemek (Gambar 7). Anak-anak yang sedang memasak biasanya menggunakan ikat rambut agar menjaga makanan tetap higienis dan tidak mengganggu proses memasak.

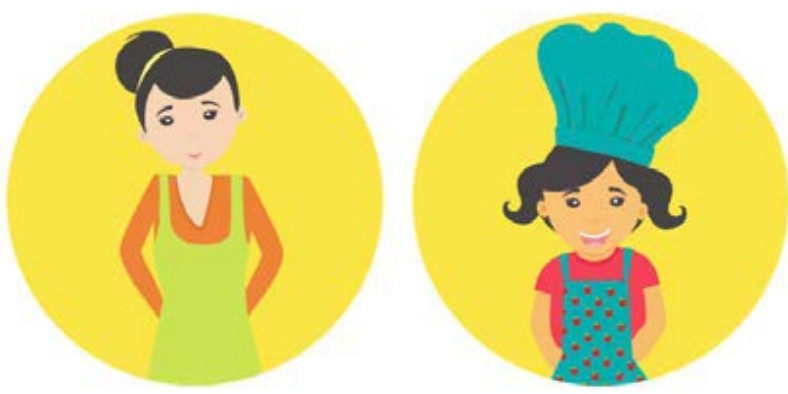

Gambar 7. Desain karakter Ibu dan anak ketika memasak 
Penggambaran environment pada aplikasi ini menggunakan data eksisting yang didapat yakni suasana dapur target audiens. Dapur pada masyarakat Indonesia pada umumnya memiliki karakteristik yakni terdapat rice cooker dan sebuah oven listrik kecil (Gambar 8). Selain itu, bahan yang digunakan dalam kitchen set biasanya berbahan kayu.

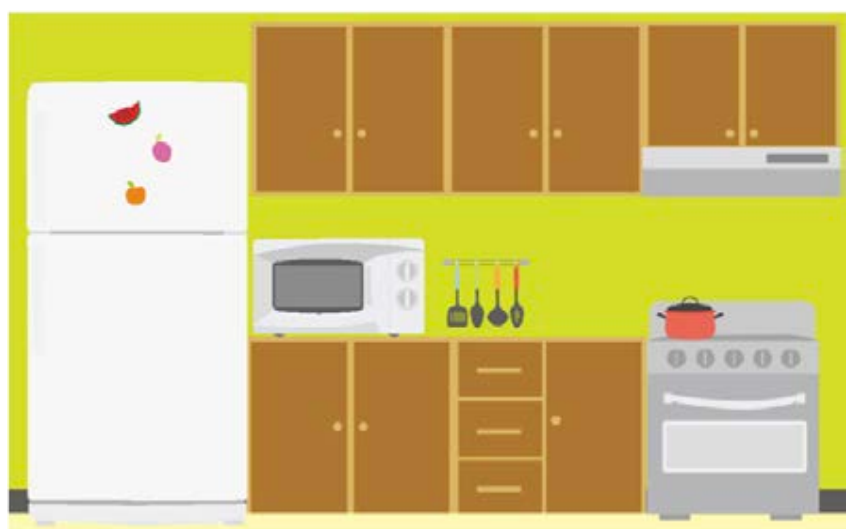

Gambar 8. Desain environment dapur

Pola navigasi yang digunakan pada perancangan aplikasi ini dipilih berdasarkan studi literatur dan kesesuaian dengan konsep desain. Pola navigasi yang digunakan adalah pola navigasi Springboard dan pola navigasi Metaphor. Tampilan pola navigasi Springboard berupa tampilan icon thumbnails yang langsung menghubungkan pada aplikasi tersebut. Pola springboard umumnya menggunakan grid 3x3, 2x3, $2 x 2$, dan 1x2, walaupun sesungguhnya tidak ada aturan khusus. Pola ini digunakan pada menu page, dimana user dapat menentukan resep yang akan dipilih untuk dipraktekkan.

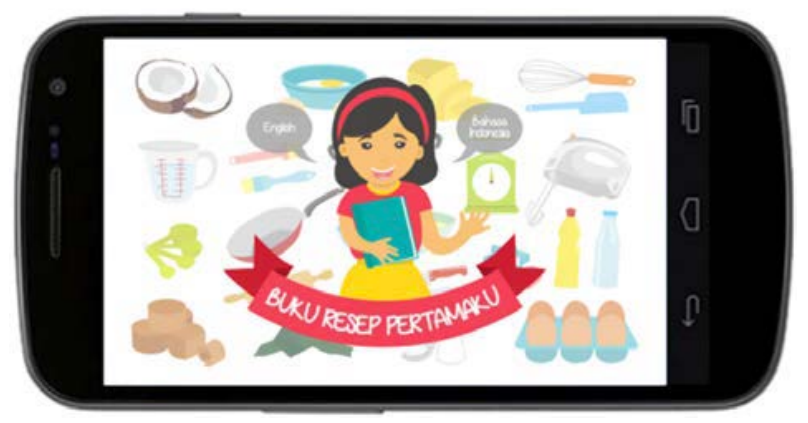

Gambar 9. Implementasi desain homepage

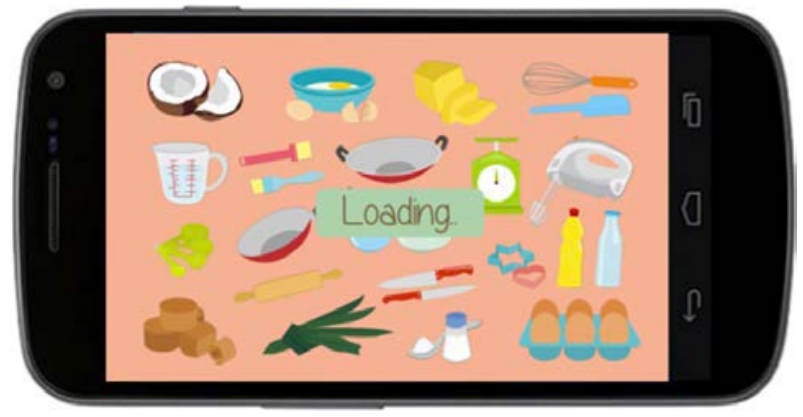

Gambar 10. Implementasi desain loading page

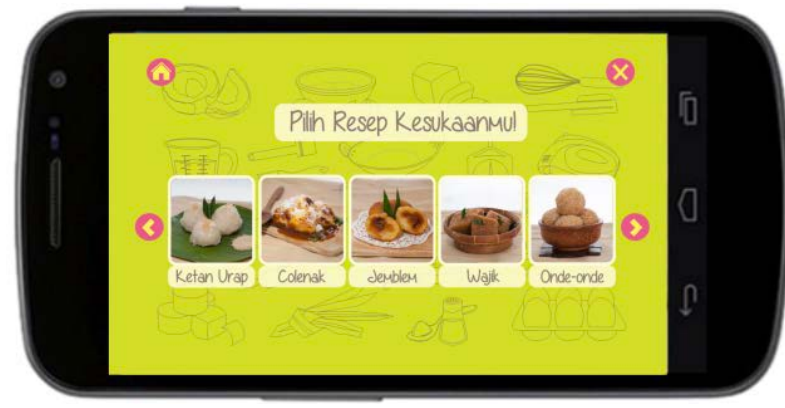

Gambar 11. Implementasi desain menu page

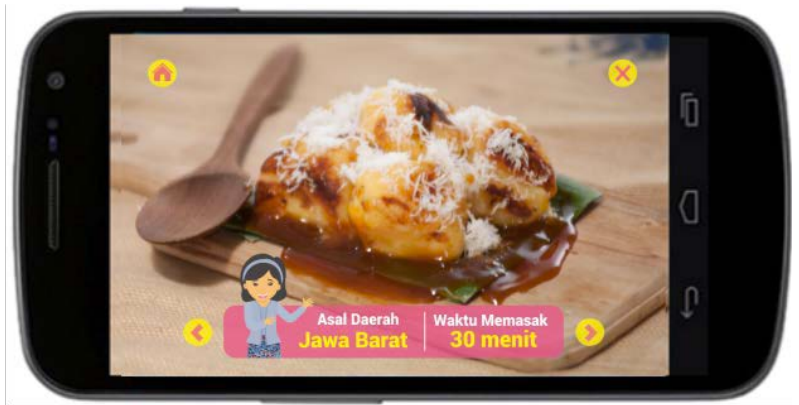

Gambar 12. Implementasi desain snack information page

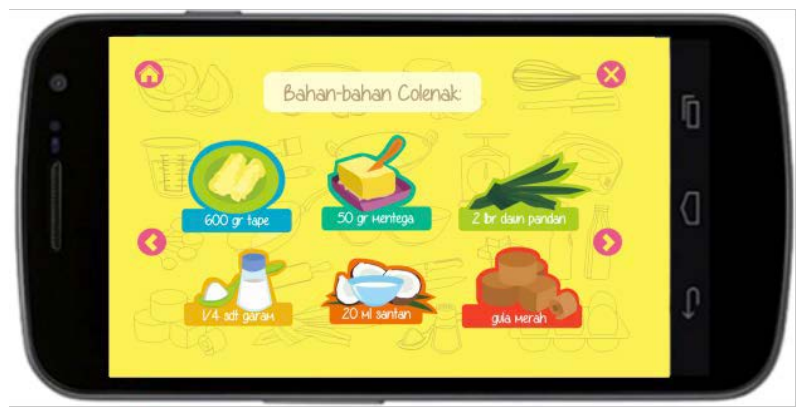

Gambar 13. Implementasi desain ingredients page 


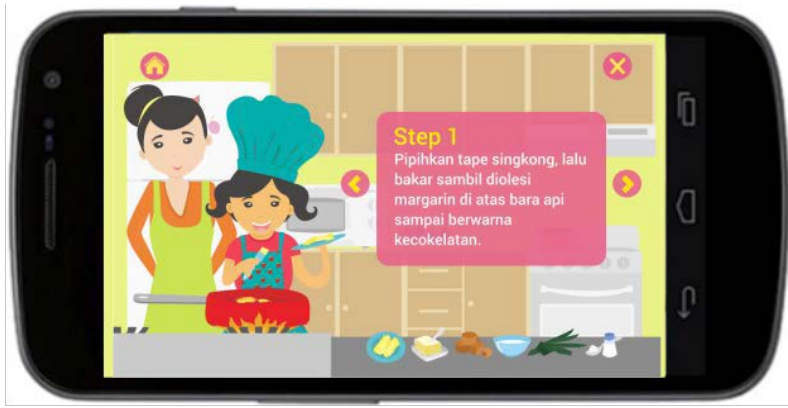

Gambar 14. Implementasi desain step by step page

Sedangkan pola navigasi Metaphor, sesuai dengan namanya pola navigasi metaphor ini memiliki tampilan menyerupai bentuk aslinya. Pola ini pada umumnya digunakan dalam aplikasi permainan, tetapi juga terdapat pada aplikasi-aplikasi lainnya. Pola ini digunakan pada tahapan step by step, dimana tampilan menyerupai bentuk dapur yang asli.

Sedangkan struktur navigasi yang dibuat, berdasarkan kebutuhan konten dan hasil analisa komparator-kompetitor dengan jenis aplikasi yang sama dan target audiens yang sama. Hal ini dimaksudkan agar, target audiens yakni anak-anak tidak merasa kesulitan untuk menggunakan aplikasi resep interaktif ini. Gambar 9-14 memperlihatkan tampilan aplikasi interaktif yang telah dirancang.

\section{Kesimpulan}

Produk aplikasi "Buku Resep Pertamaku" ini merupakan aplikasi resep interaktif yang ditujukan untuk anak-anak usia 8-12 tahun, dimana merupakan usia tahap awal dalam belajar memasak. Dengan berisikan 15 resep kue-kue tradisional yang populer di Pulau Jawa, aplikasi ini juga mengenalkan kuliner tradisional kepada anak-anak sebagai salah satu budaya Indonesia. Dan juga sebagai bentuk partisipasi dan dukungan akan masuknya era industry 4.0, yang ditandai meningkatnya konektivitas, interaksi, dan batas antara manusia, mesin, dan sumber daya lainnya yang semakin konvergen melalui teknologi informasi dan komunikas, terutama pada sektor industry makanan dan minuman, agar kuliner tradisional Indonesia lebih dapat dikenal secara global.

Aplikasi ini bersifat interaktif karena terdapat animasi pada tahapan step by step, sehingga lebih memudahkan anak-anak untuk memahami resep serta dalam mengikuti alur memasak. Selera dan ketertarikan target audiens sangat mempengaruhi desain pada alikasi ini, baik dari pembuatan karakter, pemilihan warna, serta struktur navigasi yang disesuaikan dengan penggunaan. Selain itu, aplikasi ini juga telah di uji cobakan terhadap beberapa target audiens, baik dari segi desain maupun yang dipraktekkan secara langsung.

\section{Daftar pustaka}

Burdett, K. R. (2015). The Effects of Kids' Cooking Camps on Native American Children' Knowledge and Habits Related to Food Safety, Preparation, and Nutrition. North Dakota State University of Agriculture and Applied Science.

Chu, Y. L., Farmer, A., Fung, C., Kuhle, S., Storey, K. E., \& Veugelers, P. J. (2013). Involvement in home meal preparation is associated with food preference and self-efficacy among Canadian children. Public Health Nutrition, 16(1), 108-112. https://doi.org/DOI: 10.1017/S1368980012001218

Dini. (2013). Latih Anak Memasak Sesuai Usianya. Retrieved January 18, 2013, from https://lifestyle.kompas.com/read/2013/01/18/09120719/Latih. Anak.Memasak.Sesuai.Usianya

Kementerian Perindustrian Republik Indonesia. (2018). Making Indonesia 4.0: Strategi RI Masuki Revolusi Industri Ke-4. Retrieved August 28, 2018, from http://www.kemenperin.go.id/artikel/18967/MakingIndonesia-4.0:-Strategi-RI-Masuki-Revolusi-Industri-Ke-4

McCabe, M., \& De Waal Malefyt, T. (2015). Creativity and cooking: Motherhood, agency and social change in everyday life. Journal of Consumer Culture, 15(1), 48-65. https://doi.org/10.1177/1469540513493202

Parenting Indonesia. (2013). Anak Cerdas Lewat Memasak. Retrieved July 21, 2013, from www.parenting.co.id/article/balita/anak.cerdas.lewat.memasak /001/03/544

Sartika, K. (2013). Anak Sudah Bisa Memasak Sebelum Usia 8 Tahun, Pertanda Apa? Retrieved July 21, 2013, from www.tabloidbintang.com/gaya-hidup/psikologi/67752-anaksudah-bisa-memasak-sebelum-usia-8-tahun,-pertanda-apa.html

van der Horst, K., Ferrage, A., \& Rytz, A. (2014). Involving children in meal preparation. Effects on food intake. Appetite, 79, 18-24. https://doi.org/10.1016/j.appet.2014.03.030

Wawa. (2013). Mau Makan? Latih Anak Memasak Bukan Membeli. Retrieved July 21, 2013, from https:/lifestyle.kompas.com/read/2013/06/19/18484633/Mau. Makan.Latih.Anak.Memasak.Bukan.Membeli 
Productum Vol 3 No 4 Juli-Desember 2018 pp. 125-132 